\title{
Economic Implication of Grazing and Water Resource Scarcity on Households' Welfare and Food Security in Tigrai, Ethiopia
}

\author{
Muuz Hadush
}

\begin{abstract}
In this paper, I have explored the link between grazing and water resource scarcity and per capita food consumption expenditure as a proxy for welfare and food security using distance and shadow price as a resource scarcity indicator in Northern Ethiopia based on a unique data set for 518 sample farmers. To address my objectives, I employed an IV 2SLS model for estimating welfare and probit for analyzing food security, drawing on a separable farm household model. My results confirmed the theoretical prediction that grazing and water affect households' welfare and food security adversely, as predicted by the downward spiral hypothesis.
\end{abstract}

Key Words: Ethiopia, food consumption, food security, IV, resource scarcity, Tigrai, welfare

Many studies have established that the rural poor in developing countries are heavily dependent on local natural resources for their sustenance (e.g., Narain, Gupta, and Van't Veld 2008) and that degradation of resources hurts the poor more (Khan 2008). The downward spiral hypothesis states that people in poverty are forced to deplete resources to survive, and this environmental depletion further impoverishes them (Ostrom et al. 1999). Land degradation in Sub-Saharan Africa (SSA) remains a substantial problem, spurring rural poverty (Bhattacharya and Innes 2006, Tesfa and Mekuriaw 2014). It directly aggravates poverty by reducing the availability of environmental goods and services and by increasing the labor input needed

Muuz Hadush is a lecturer at Mekelle University, Department of Economics and $\mathrm{PhD}$ student at Norwegian University of Life Sciences (NMBU), School of Economics and Business. Correspondence: Muuz Hadush - Norwegian University of Life Sciences (NMBU) - School of Economics and Business - Box 5003 - 1432 Ås, Norway - Email: muuz.hadush.gebremichael@nmbu.no and muuz.hadush@mu.edu.et

This research has been sponsored by the collaborative research and capacity-building project on Climate Smart Natural Resource Management and Policy (NORHED-CLISNARP) between Mekelle University and Norwegian University of Life Sciences. The NORHED-CLISNARP project (NORHEDCLISNARP-ETH-13/2015) and this fieldwork research were funded by the Norwegian Agency for Development Cooperation (NORAD) and the Quota Scholarship programme of StatensLånekasse for Utdanning. Special thanks also go to my supervisor, Professor Stein Holden (NMBU), Norway, for his unreserved advice and my co-advisor, Dr. Mesfin Tilahun (MU), for his assistance.

Agricultural and Resource Economics Review 48/1 (April 2019) 170-198

(C) The Author(s) 2018. This is an Open Access article, distributed under the terms of the Creative

Commons Attribution licence (http://creativecommons.org/licenses/by/4.0/), which permits unrestricted re-use, distribution, and reproduction in any medium, provided the original work is 
to seek such goods in East Africa (Lal and Stewart 2010, Bezabih and Berhane 2014). World Bank (2012) reported that the cost of environmental degradation is almost 8 percent of the GDP across countries, consisting of 40 percent of the developing countries.

Livestock production depends on quantity and quality of feed and water. About 10 percent of cropland is used to produce crop residues for feeding livestock, and animals in the extensive system need more water per animal (Bezabih and Berhane 2014). Increasing scarcity of grazing and water for an animal can be a significant burden to households, because grazing and water are key factors in livestock production. Thus, the scarcity of these resources may impact agriculture by reallocating production factors such as labor from agriculture, food preparation, and leisure activities into searching for and collecting the resources. Reductions in agricultural output stemming from reduced labor input are likely to have detrimental welfare and food security consequence (Kumar and Hotchkiss 1988, Cooke 1998, Alemu, Damte, and Deribe 2015). The critical shortage of water and feed for an animal has negative implications for agricultural production and food security, particularly for poor people who rely on agriculture as a source of food and spend considerable time collecting these resources (Yilma et al. 2011, Alemu, Damte, and Deribe 2015).

Poverty and resource degradation appear to go hand in hand in SSA. Resource degradation, by all accounts, is rampant in the region. In many studies of Africa, feed and water scarcity are frequently mentioned constraints for animal farming activities (Tegegne 2012, Bezabih and Berhane 2014). In Ethiopia, resource depletion has contributed to the existing problem of food insecurity and is still a real threat to the agricultural farming (Bewket 2011). In the study area, environmental depletion has reached a critical stage, posing a major threat to agriculture production and welfare Gebreegziabher et al. 2009). Grazing and water scarcity may be less problematic in developed countries where there are available substitutes but can have a huge impact on household welfare in Developing countries such as Ethiopia. Households with scarcity may walk longer distances to search for and collect these resources, leaving less labor for leisure and food production and preparation (Cooke, Köhlin, and Hyde 2008, Bezabih and Berhane 2014).

The literature suggests that as a result of increasing resource scarcity, many households increase the time they spend on collecting them. Overall, the scarcity has negative implications for agricultural production and food security by diminishing households' food supply and incomes, and hence their capacity to acquire food and nutrition (Tangka and Jabbar 2005, Cooke, Köhlin, and Hyde 2008, Damte, Koch, and Mekonnen 2012, Alemu, Damte, and Deribe 2015). Cooke (1998) revealed that most of the reallocated time for searching and collecting the scarce resources comes from leisure before agricultural labor time is reduced. One early analysis conducted by Bandyopadhyay, Shyamsundar, and Baccini (2011) also indicates that the amount of biomass negatively affected rural per capita consumption 
expenditure in Malawi. Grazing and water scarcity in Ethiopia can affect household welfare in different ways. Poor farmers may not have access to alternative feed resources and may increase the time spent on searching for grazing and water and straw collection, reducing time on farming activities, food preparation, leisure, or household care. Thus, under situations where markets are imperfect, increasing resource scarcity can force households to reallocate labor, thereby reducing welfare.

While the above studies estimate the effect of resource scarcity on time allocation and time reduction for farming, no study of which I am aware examines the economic effect of grazing and water scarcity on welfare, which is ultimately what policymakers seek to know (Tangka and Jabbar 2005, Cooke, Köhlin, and Hyde 2008, Khan 2008). In this study, I estimate the effect of grazing, water, and straw scarcity on per capita food consumption expenditure (PCFE) (welfare) and food security using distance and shadow price $^{1}$ as a proxy for scarcity indicator of these resources by exploiting household survey from Northern Ethiopia. My analysis is organized around four questions. First, what is the effect of resource scarcity on welfare (PCFE)? Second, how does resource scarcity affect household food security? Third, does the effect worsen the top quantile? Fourth, what is the total welfare effect of the scarcity?

In line with this, I hypothesize that the scarcity has a negative effect on households' food security and welfare (PCFE) either by affecting livestock production directly, affecting crop and off-farm income, or through direct impact on time for leisure consumption drawing on a separable farm household model. I also hypothesize that the effect of these scarce resources is not uniform across the food consumption distribution. In aggregate, the principal findings confirmed the theoretical prediction that resource scarcity affects household welfare (PCFE) and food security adversely as predicted by the downward spiral hypothesis. The estimated result from both distance and shadow price revealed that reducing time spent for searching for water, grazing, and collecting crop residue leads to an increase in welfare (PCFE) and food security.

This paper builds on the existing literature in a number of respects. In this paper, I contribute to the literature by using a unique dataset to investigate how the distance to or the shadow price of water, grazing, and crop residue affects PCFE and food security. I am able to estimate causal relationships with our data because, unlike previous studies, I collected information on the entire set of consumption expenditure, along with the distance to grazing, water, and crop residue for each household. Furthermore, unlike the previous studies, I use distance and shadow price as a proxy measure of resource

1 See for a similar approach in the work of (Cooke 1998; Cooke et al. 2008; Baland et al. 2010) 
scarcity. This paper joins the relatively scarce empirical literature on this topic in Africa - one that is dominated by South Asian cases such as $\mathrm{Nepal}^{2}$.

\section{Review of Background and Empirical Literature}

The contribution of livestock to the world's food supply, family nutrition, income, employment, soil fertility, and transport contributes to food security and poverty reduction (Randolph et al. 2007). Livestock also provides a safety net in the form of liquid assets and a strategy of food production diversification (Freeman et al. 2007). In Ethiopia, the agricultural sector is a cornerstone of the people's economic and social lives. Livestock contribution accounts for 40 percent of total agricultural GDP, excluding the values of draft power, manure, and transport service (Asresie and Zemedu 2015). Despite its large population size, the contribution of livestock production to agriculture is deteriorating (Ilyin 2011). Livestock production in Ethiopia depends on the quantity of grazing, feed, and water (Bezabih and Berhane 2014). This sector is a key player in increasing water use and water depletion (Steinfeld et al. 2006).

Both human and livestock suffer from its shortage. Most of the year, animals have to walk long distances in search of water. Despite that major feed resources are crop residues and natural pasture, their availability is gradually declining as a result of crop expansion, settlement, and land degradation (Yimer 2005, Gebremedhin 2009). With regard to this, Hassen et al. (2010) revealed that shortage of water and feed are common problems in the dry season as opposed to the wet season. The case study by Belay et al. (2013) indicated that the most important problems of livestock production perceived were feed shortage (100 percent) and water shortage (27 percent) during the dry season in Ethiopia.

Poor farmers, who are directly dependent on these local natural resources are highly affected by resource scarcity. Cooke (1998) revealed that reallocation of time away from leisure occurred as environmental goods become scarcer in Nepal. Kumar and Hotchkiss (1988) suggested that deforestation has adverse effects on agricultural production, food consumption and nutrition in Nepal. In addition, Tangka and Jabbar (2005) show that feed scarcity in Kenya increases livestock traveling distances in search of feed and water that increase household' time for collection, resulting in lower livestock and crop output, which further diminishes households' food and nutrition security. Likewise, Cooke, Köhlin, and Hyde (2008) found a negative effect of resource scarcity on health, labor burden, and agriculture in Nepal. Bhattacharya and Innes (2006) highlighted that forest degradation spurs rural poverty in SSA. According to Bandyopadhyay, Shyamsundar, and Baccini (2011), in Malawi,

2 For a detail review of related empirical studies, see Cooke et al. (2008). 
more time spent on scarce fuelwood collection was associated with negative welfare.

Dasgupta (2007) warns that the average per capita consumption level may decline with degradation of resources. Aggrey et al. (2010) showed that deforestation and degradation were positively linked with poverty in Uganda. The findings of Khan (2008) in Pakistan supported that environmental degradation hurts the poor the most. Baland et al. (2010) indicate that an increase in firewood collection time lowers the living standards of households in Nepal. Aluko (2004) showed that deterioration in the quality of life increases with increasing environmental degradation in Niger. Alemu, Damte, and Deribe (2015), in their analysis, show that fuelwood scarcity has a negative impact on time spent on agriculture; however, scarcity of water has no effect on time spent on agriculture in Ethiopia. Likewise, Mekonnen et al. (2017) indicated that agricultural productivity decreases with increasing time spent on collecting animal dung but increases with time spent on collecting crop residue. Boone, Glick, and Sahn (2011) suggest that a long distance to a water source increases water-gathering time in Madagascar.

In spite of the recognized contributions of the existing studies, none of the above studies examine the effect of grazing and water on welfare and food security (Tangka and Jabbar 2005, Cooke, Köhlin, and Hyde 2008). Therefore, this study makes a noteworthy contribution in pointing out the relevance of improving feed and water management for the animal.

\section{Theoretical Model}

The contribution of livestock to food and nutritional security in developing countries is significant (Swanepoel et al. 2010). In a mixed crop-livestock, Ethiopia owns a significantly large livestock population, and its production mainly depends on natural resources such as grazing land, water, and crop residue (Bezabih and Berhane 2014). Ethiopian farmers usually experience a serious seasonal fluctuation in fodder and water availability for the animal. The dependence on these resources implies that scarcity can have a huge impact on household welfare (Bewket 2011, Bezabih and Berhane 2014). In rural farm households, in which the farmer is engaged in both crop and livestock production activity, total time endowment is divided into three main activities: farm activities, off-farm activities, and leisure. However, considering the scarcity of these resources, the total time endowment will further include a fourth activity - collecting scarce resources.

I start with the downward spiral hypothesis that states that people in poverty are forced to deplete resources to survive, and this environmental depletion further impoverishes them (Ostrom et al. 1999). It is supposed that the scarcity of resource can affect household well-being either by affecting livestock production directly, affecting crop and off-farm income (via labor reallocation) or through its direct impact on time for food preparation or leisure consumption (Cooke, Köhlin, and Hyde 2008, Alemu, Damte, and 
Deribe 2015). To conceptualize the effect of resource scarcity on welfare and food security, I develop a theoretical model within the framework of household utility model following the work of Strauss (1986) and later Faridi and Wadood (2010), which fits in to the separable farm household model. I suppose that rural households are characterized as both producers and consumers of their food; thus, a household strictly quasi-concave utility function based on the framework of consumer demand and production theories is presented as follows:

$$
U_{i}=U\left(C_{i}, C_{n}, C_{m}, L_{l} ; \Gamma\right)
$$

where $U_{i}$ is a utility function that is twice differentiable, increasing in its arguments and strictly quasi-concave; $C_{i}$ and $C_{n}$ are vectors of homeproduced food and nonfood goods consumed by the $i^{\text {th }}$ household; $C_{m}$ is a market-purchased good consumed, $L_{l}$ is leisure, and $\Gamma$ is the vector of household sociodemographic variables. $C_{n}$, in this case represents the demand for nonfood items such as education, health, and housing. Equation 1 leads us to the generalized utility function developed by Becker (1991), which requires that production decision is first made to maximize profit and household maximizes utility using this maximum profit consecutively (Strauss 1986). The meal production is a function of agricultural goods $\left(Q_{i}\right)$, off-farm income $(E)$, fuel sources such as straw or dung $\left(E_{f}\right)$, and labor days the household would spend on searching for grazing land, water, and crop residue $\left(L_{c}\right)$, The production of household goods is also influenced by the vector of household characteristics

$$
C_{i}=C\left(E_{f}, Q_{i}, E, L_{c} ; \phi\right) .
$$

The rural household is assumed to maximize its utility subject to farm production, income, and time constraints specified as:

$$
F\left(Q_{i}, L, L_{c}, K, A\right)=0 .
$$

Equation 3 is a typical household implicit production function for food, $Q_{i}$ produced at home and assumed to be twice differentiable, increasing in outputs, decreasing in inputs, and strictly convex; $L$ is the total labor input used on the farm; $L_{c}$ is the time spent on searching for grazing, water, and collecting crop residue; $K$ is the fixed capital stock, $A$ is the farm size; labor time is an important resource denoted by $T$, and it is allocated among crop farming activities $L_{a}$, searching for and collecting scarce resource $L_{c}$ and leisure $L_{l}$ supplied by the household:

$$
L_{a}+L_{c}+L_{l} .
$$


At the same time, the income constraint for the rural household is given by

$$
P_{i}\left(Q_{i}-C_{i}\right)-P_{n} C_{n}-P_{m} C_{m}-W\left(L-L_{a}\right)+E=0 .
$$

$P_{i}$ is the price of price of food produced; $P_{i} Q_{i}$ is a marketed surplus of produced good; $P_{n}$ is the price of nonfood goods; $P_{m}$ is the price of a marketpurchased good; $W$ is the wage rate; $L_{a}$ is total family labor supply for onfarm use; $E$ is nonfarm income. Substituting the right-hand side (RHS) of equations 4 into 5 yields:

$$
P_{i}\left(Q_{i}-C_{i}\right)-P_{n} C_{n}-P_{m} C_{m}-W\left(L-\mathrm{T}+L_{c}+L_{l}\right)+E=0 .
$$

Expanding and rearranging equation 6 produces an explicit household income and expenditure:

$$
P_{i} Q_{i}+W \mathrm{~T}+E-W L-W L_{c}=P_{i} C_{i}+P_{n} C_{n}+P_{m} C_{m}+W L_{l} .
$$

The left-hand side of equation 7 represents household's full income, which comprises the value of farm produce $P_{i} Q$, the value of time endowment $W \mathrm{~T}$, nonfarm income $E$, the value of labor used for farming including the hired labor $W L$ and value of labor spent for searching and collecting scarce resources $W L_{c}$. Similarly, the right-hand side of equation 7 is the household expenditure on food and leisure. The expenditure side includes purchases of its own produce food consumed, $P_{i} C_{i}$; the value of nonfood expenditure $P_{n} C_{n}$, the value of market purchase food consumed $P_{m} C_{m}$, and purchase of leisure $W L_{l}$. The optimization of equation 1 yields an income and expenditure equation within the separability assumption. At an interior solution, the household selects $L_{c}, L_{l}, L, C_{i}$ and $C_{m}$ to maximize equation 1 subject to equations 7 and 3, which can be best visualized as:

$$
\begin{aligned}
\mathcal{L}= & U\left(C\left(E_{f}, Q_{i}, \mathrm{E}, L_{c} ; \phi\right), C_{n}, C_{m}, L_{l} ; \Gamma\right)+\lambda\left(P_{i} Q_{i}+W \mathrm{~T}+E-W L-W L_{c}\right) \\
& -\left(P_{i} C_{i}+P_{n} C_{n}+P_{m} C_{m}+W L_{l}\right)+\gamma\left[\mathrm{F}\left(Q_{i}, L, L_{c}, K, A\right)\right] .
\end{aligned}
$$

Based on Strauss (1983), it is possible via optimization of equation 8 yield production and consumption equations separately as discussed below. The first order conditions are:

$$
\begin{gathered}
\frac{d \mathcal{L}}{d L_{c}}=\frac{d U}{d C} \frac{d C}{d L_{c}}-\lambda W+\gamma \frac{d F}{d L_{c}}=0 \\
\frac{d \mathcal{L}}{d L_{l}}=\frac{d U}{d L_{l}}-\lambda W=0
\end{gathered}
$$




$$
\begin{gathered}
\frac{d \mathcal{L}}{d L}=\gamma \frac{d F}{d L}-\lambda W=0 \\
\frac{d \mathcal{L}}{d C_{i}}=\frac{\partial U}{\partial C_{i}}-\lambda P_{i}=0 \\
\frac{d \mathcal{L}}{d C_{m}}=\frac{\partial U}{\partial C_{m}}-\lambda P_{m}=0 \\
\frac{d \mathcal{L}}{d C_{n}}=\frac{\partial U}{\partial C_{n}}-\lambda P_{n}=0
\end{gathered}
$$

Maximizing the first-order condition of the LHS of equation 8 with respect to labor $\left(L^{*}\right)$ and output produced $\left(Q^{*}\right)$, the demand for inputs and output is derived in terms of all prices, the wage rate, time for searching and collecting scarce resource, fixed land, and capital as:

$$
\begin{aligned}
L^{*} & =I^{*}\left(P_{i}, P_{m}, P_{n}, W, L_{c}, K, A\right) \\
Q^{*} & =Q^{*}\left(P_{i}, P_{m}, P_{n}, W, L_{c}, K, A\right)
\end{aligned}
$$

Substituting optimal labor, $L^{*}$ and optimum output $Q^{*}$ into LHS of equation 7 produces optimum income/full income $Y^{*}$ under the assumption of maximized profit $\pi^{*}$ as:

$$
\begin{gathered}
Y^{*}=P_{i} Q^{*}+W \mathrm{~T}+E-W L^{*}-W L_{c} \\
Y^{*}=W \mathrm{~T}+\pi^{*}\left(P_{i}, P_{m}, P_{n}, W, L_{c}, K, A\right)+E
\end{gathered}
$$

where $\pi^{*}\left(P_{i}, P_{m}, P_{n}, W, L_{c}, K, A\right)$ represents $P_{i} Q^{*}-W L^{*}-W L_{c}$.

The first order conditions of the RHS of equation 7 give consumption demand function in terms of prices, wage rate and income, and household's preferences represented by household demographic characteristics $\Gamma$. This relationship can be specified as:

$$
C_{d}=c\left(P_{i}, P_{m}, P_{n}, W, L_{c}, Y^{*}\left(P_{i}, P_{m}, P_{n}, W, L_{c}, K, A, E\right) ; \Gamma\right) .
$$

The above equation states that household food consumption $C_{d}$ is mainly influenced by both food and nonfood prices, wages, resource scarcity and household income. Referring to household demand for food as a measure of household food security (FS), then $C_{d}$ is a reduced form of the utility function of equation 1, which allows the evaluation of the effects of demographic and economic variables. Food security is approximated by food consumption expenditure $^{3}$ in this case.

\footnotetext{
3 See for a similar approach (Smith and Subandoro 2007; Çağlayan and Astar 2012; Gaiha et al. 2014; Mignouna et al. 2015)
} 
The effect of scarce resources on agricultural production is investigated through the production sector, and its direct impact on household's utility is explored through the consumption sector. Thus, the total effect that is the sum of the two effects can be further explained using equation 11. Because time spent for searching for grazing or water and collecting straw is one explanatory variable of agricultural output function, the total effect of this variable on per capita food expenditure is:

$$
\frac{d C_{d}}{d L_{c}}=\frac{d C_{d}}{d Y} \frac{d Y}{d L_{c}}+\frac{d C_{d}}{d L_{c}} .
$$

Then, the total effect is simply calculated by taking the slope coefficient of income in the consumption regression multiplied by the coefficient of time allocation in the production estimation, plus the coefficient of time allocation in the consumption regression.

\section{Description of the Study Area and Dataset}

The study is conducted in the Tigrai region, the northern part of Ethiopia, by randomly selecting 632 sample households. In this region, feed and water deficits start in December, when the natural pastures are at their lowest quantity, and the supply of stored crop residues is starting to diminish (Sileshi, Tegegne and Tsadik 2003). Likewise, Gebremedhin (2009) and Yimer (2005) also revealed that natural grazing is diminishing over time due to the high degree of degradation, resulting in high tropical livestock unit (TLU) per $\mathrm{km}^{2}$ of grazing land. The estimated crop residues are found to be about $1,229,651$ tons of dry matter per year while the region has an estimated 878,322 ha of arable land available for crop production, contributing about 45 percent of the animal feed demand. Felleke and Geda (2001) also stated that 73 percent of the feed is provided from natural grazing, 14 percent from crop residues, and the remaining 13 percent from other feed sources. A recent study by Bishu (2014) in Tigrai indicated that there is a livestock drinking water shortage (34 percent) and feed shortages (7 percent). There is also a livestock management labor shortage (Tegegne 2012).

This study used cross-sectional data from NMBU-MU 4 Tigrai Rural Household Survey dataset collected in 2015. The data include a panel of five rounds conducted in 1997/1998, 2000/2001, 2002/2003, 2005/2006 and 2014/ 2015 , in which the author was involved only in collecting the data for the last round. The primary data used in this paper are adapted from the last, 2014/ 2015, household survey. Table 1 presents the summary of basic variables of

4 NMBU-MU refers to Norwegian University of Life Science-Mekelle University. 
Table 1. Descriptive and Summary Statistics

\begin{tabular}{|c|c|c|c|}
\hline \multirow[b]{2}{*}{ Variables } & \multicolumn{3}{|l|}{$N=\mathbf{5 1 8}$} \\
\hline & Description & Mean & SD \\
\hline \multicolumn{4}{|l|}{ Dependent Variables } \\
\hline $\mathrm{FE}$ & Monetary value of food expenditure & 13571.4 & 19717.4 \\
\hline PCFE & $\begin{array}{l}\text { Monetary value of per capita food } \\
\text { expenditure (ETB) }\end{array}$ & 2,490 & 3,722 \\
\hline Output & $\begin{array}{l}\text { Monetary value of crop production } \\
\text { (ETB) }{ }^{\mathrm{a}}\end{array}$ & 41,645 & 87,517 \\
\hline FI & Food Security Index ${ }^{b}$ & 0.4826 & 0.5001 \\
\hline \multicolumn{4}{|l|}{ Independent Variables } \\
\hline ShadowPW & Shadow price of water & 147.6 & 204.9 \\
\hline ShadowPG & Shadow price of grazing & 205.0 & 282.0 \\
\hline ShadowPF & Shadow price of crop residue & 12.52 & 18.96 \\
\hline WaterD & $\begin{array}{l}\text { Distance to animal water source in } \\
\text { minutes per day }\end{array}$ & 74.85 & 65.54 \\
\hline GrazingD & $\begin{array}{l}\text { Time spent looking for grazing land in } \\
\text { minutes per day }\end{array}$ & 91.12 & 83.44 \\
\hline FeedD & $\begin{array}{l}\text { Time to transport crop reside in } \\
\text { minutes per trip }\end{array}$ & 576.55 & 557.87 \\
\hline Income & Monetary value of total income $(\mathrm{ETB})^{\mathrm{c}}$ & 49521 & 92,642 \\
\hline Family size & Household family size & 5.873 & 2.413 \\
\hline Age & Household head age & 56.83 & 15.20 \\
\hline Gender & $1=$ Male & 0.743 & 0.437 \\
\hline Education & $1=$ literate & 0.326 & 0.469 \\
\hline TLU & Herd Size in Tropical Livestock Unit & 3.919 & 3.199 \\
\hline MarketD & Market distance in minutes & 82.30 & 54.79 \\
\hline Shocks (2012-2014) & $\begin{array}{l}\text { Number of shocks due to theft, flood, } \\
\text { death }\end{array}$ & 0.577 & 0.826 \\
\hline Information & $1=$ access to $\mathrm{TV}$, radio $\&$ mobile & 0.417 & 0.494 \\
\hline Location & $1=$ highland $(>2500$ masl $)$ & 0.0637 & 0.244 \\
\hline Network & $1=$ support from relatives $\&$ friends & 0.610 & 0.488 \\
\hline Religion & $1=$ orthodox \& 0 Muslim & 0.824 & 0.381 \\
\hline Ashock13 & $1=$ face animal shock in 2013 & 0.0425 & 0.202 \\
\hline
\end{tabular}

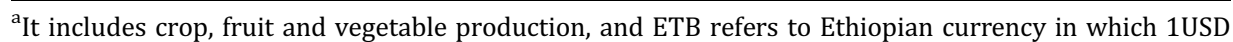
$\sim 23$ ETB during the study period.

${ }^{\mathrm{b}} \mathrm{A}$ household is considered food secure if it attains at least two-thirds of the average PCFE of all households and considered food insecure if it falls below that value.

${ }^{\mathrm{c}}$ It includes income from agriculture, off-farm, business transfer and safety net. 
518 farm households drawn from 632 sample farmers. The need for information regarding livestock activity restricted us to using only 518 livestock owner-farmers for this study.

On the welfare side, the dependent variable is PCFE 5 . For each household, expenditure profile on the following seven food groups were recorded: (1) staple foods, including cereals and pulses, (2) meat, egg, and fish, (3) dairy products, (4) fruits and vegetables, (5) fats and oils, (6) sugar and honey, and (7) miscellaneous such as tea and coffee. Likewise, the dependent variable on the production side is an aggregate monetary value of all crops produced during the survey production season. An average household has produced an average agricultural output worth 41,645 ETB, and the average total income including sales from agricultural outputs is worth 49,426 ETB. Households, on average, spend approximately 13571 ETB for food with an average PCFE of 2,490 ETB in the year. I also construct the food security dependent variable by classifying households into food secure and food insecure using a food security index calculated by dividing the individual PCFE to a two-thirds average PCFE of all households ${ }^{6}$. Accordingly, a household is considered food secure if it attains at least two-thirds of the average per capita food expenditure of all households and considered food insecure if it falls below that value.

The results in Table 1 showed that 48 percent of the households were food secure, while 52 percent were food insecure, given that two-thirds of the average of all households is 1660 ETB. Feleke et al. (2005) documented about 40 percent incidence of food insecurity in Ethiopia. Regarding the scarcity indicator, we know that grazing land and water resources are challenging to value because they are not traded and have no market price. Their prices are a shadow price (Magnan, Larson, and Taylor 2012) because shadow prices are assumed to better reflect the economic scarcity of environmental goods to a household (Cooke 1998). For this reason, as a proxy indicator for scarcity, first, I use walking distance in minutes for a single trip to measure grazing, water per day and crop residue per trip using an approach similar to that used by Palmer and MacGregor (2009). On average, the households spend $1.25 \mathrm{~h}$ to reach a water source for animals and $1.5 \mathrm{~h}$ to search for communal grazing land daily, with the maximum time reaching up to $6 \mathrm{~h} /$ day for water site and $8 \mathrm{~h} /$ day for grazing land in the data. Besides, the average time spent on collecting crop residue by the households is $9.6 \mathrm{~h}$ per a single trip.

Second, following Baland et al. (2010), Cooke (1998), and Alemu, Damte, and Deribe (2015), I measure the shadow price of searching for grazing

\footnotetext{
5 Thirumarpan (2013) and Asfaw et al. (2012) used consumption expenditure to reflect the socioeconomic welfare of households and is a reliable indicator of food accessibility and degree of vulnerability to food insecurity.

6 The same approach is found in the work of Titus and Adetokunbo (2007).
} 
and water as well as collecting crop residue for an animal as the time taken to search for grazing land and water per animal or to collect crop residue per its amount collected multiplied by the village median adjusted ${ }^{7}$ off-farm wage. Cooke (1998) and Alemu, Damte, and Deribe (2015) use the shadow price of fuelwood, leaf fodder, water, and grass to measure scarcity. In this paper, I take the wage rate at the village level, and thus there is no variation in wages for households living within the same village. In this way, I produce a household specific shadow price of searching for grazing land or water and collecting straw. Table 1 reported that the average shadow price for animal watering is about 147 ETB per day, which is equivalent to the average daily rural wage rate in the region. On average, the opportunity cost of searching grazing is 205 ETB per day, which is greater than the opportunity cost of water and straw. This is not surprising because rural farmers usually spend a huge amount of time in searching for grazing than for watering. As expected, the shadow price of collecting a residual crop is 12 ETB per trip.

Out of the total sample, 6.4 percent lives in the highland parts of the region. Nearly 39 percent of the households report that they have been severely affected by 11 different level of shocks including, drought, pests, flood, theft, illness and death, loss of job, and home damage in the last harvesting season, and 4.25 percent of households report having been affected by animal shocks one year before the harvesting season. Seventy-four percent of the households are male heads, with an average age of 57 and family size of 5.87. Because resources are scarce, high family size may put much more pressure on consumption than it contributes to production.

Nearly 32 percent of the household heads have at least one or more years of primary school education. Thus, it is hypothesized that education is negatively related to consumption value. Around 82 percent of the households are Orthodox followers, while 18 percent of the households are Muslim households in the study area. Out of the 518 households in the sample, 61 percent got assistance either from their relatives or friends and are expected to increase production and consumption (Di Falco et al. 2011). More than 40 percent of household heads attend media via TV, radio and mobile phone about any development intervention. Hence, it is expected that households with information are more likely to produce more and be food secure. The expected effect on production and consumption is positive (Di Falco et al. 2011). In addition, the average livestock endowment of the sample households is $4 \mathrm{TLU}$, which is expected to increase food security.

\footnotetext{
To adjust for big variation in the wage rate among villages of the region, the wage rate is adjusted using a general informal rural labor conversion factor, 0.98 .
} 


\section{Econometric Model Specification}

In order to estimate the consumption side, the researcher is forced to approximate welfare by PCFE due to limited data ${ }^{8}$. Assuming that the demand equation from the utility maximization of the recursive household model has a functional form of log-linear, its capability of estimating respective elasticities as its coefficient and modeling nonlinear effects makes it applicable and preferable (Oum 1989). Oum added that the log-linear demand function resembles the demand function obtainable from a CobbDouglas utility function with the drawback of invariant estimated elasticities across all data points. The aggregate demand equation per household is estimated for PCFE rather than estimating single demand equations for each product consumed or for each individual member of the household. Following Adewuyi, Mafimisebi, and Awe (2009) and Babalola and Isitor (2014), the implicit form of the OLS is given as:

$$
\ln C_{d}=\delta+\delta Y_{i}+\sum_{k=1}^{K} \beta_{k} \ln X_{i}+v,
$$

where $-\ln C_{d}$ is households' PCFE; $Y_{i}$ is a rural farm and off-farm income; $X_{i}$ for $k=1 \ldots K$, includes consumption side variables and household characteristics; $X_{1}$ is aggregate monetary value of crop production; $X_{2}$ is herd size in TLU; $X_{3}$ is family size; $X_{4}$ is gender of the household head with male being equal to $1 ; X_{5}$ refers to the access of information via radio, TV, and mobile in binary form; $X_{6}$ reflects the agro-ecological location of each household measured by GPS but classified as highland if it is 2500 masl and lowland if it is below that; $X_{7}$ represents market distance in minutes; $X_{8}$ and $X_{9}$ correspond to the dummy exposure of animal shock in 2013 and cumulative number of shocks from 2012-2014; $X_{10}=1$ if the household is reported to be orthodox; $X_{11}=1$ if the household gets assistance from relatives and friends, while $X_{12}$ and $X_{13}$ capture the age of house head in years and total farm income composed of farm income, off-farm income, business transfer, and safety net income. The resource scarcity is captured by the walking distance to the water source in minutes/ day/trip $\left(X_{14}\right)$, walking distance to the grazing source in minutes/day/trip $\left(X_{15}\right)$ and walking distance to the crop residue site in minutes/trip $\left(X_{16}\right)$ per year.

$v$ is an error term. Because farm and off-farm income are not randomly distributed among rural households, this variable is likely to be endogenous (Hoddinott et al. 2008), which could be caused by omitted variables, measurement error, simultaneity, or household unobservable. First, a reverse causality problem might exist, because PCFE at the household level might also influence labor productivity and thus farm productivity. Second, farm

8 Check Asfaw et al. (2012) and Thirumarpan (2013) for similar work. 
and off-farm income might be influenced by household unobservable, which can lead to a correlation with the error term. In the presence of endogeneity, the use of the OLS estimator biases the effect of income (Wooldridge 2009).

In order to avoid an endogeneity bias, I adopted a two-stage least square (2SLS) approach which is the most common instrumental variable estimator (Angrist and Evans 1998), where rural farm income is instrumented by shock exposure and average rainfall of 2003-2014. This is similar to approaches that have been used by Sarris, Savastano, and Christiaensen (2006), Hidalgo et al. (2010), and (Abdulai and Huffman 2014) in different contexts.

Shock caused by crop theft, illness, and death of a household member is expected to affect income and output negatively, thereby reducing food expenditure (Dercon et al. 2005, Abdulai and Huffman 2014). The explanation is that farm income is expected to decrease with increasing any shock on crop or animal farming caused by a theft or illness of the household. Then its effect on consumption reaches through its effect on farm income. Our justification for using rainfall is that average shortfall of rainfall influences rural farm income without directly influencing the consumption expenditure in the village (Hidalgo et al. 2010). Increasing rainfall is expected to increase farm income directly but consumption indirectly through its effect on income. With this procedure, the structural equation is specified as

$$
\ln C_{d}=\delta+\delta^{i v} \hat{Y}+\sum_{k=1}^{K} \beta_{k} \ln X_{i}+\varepsilon,
$$

where $\ln C_{d}$ is PCFE, $\hat{Y}$ is the predicted values of the endogenous rural income variables, $\varepsilon$ is an error term, and $\beta$ is the parameter coefficient of the vectors of an exogenous variable, $X$. To obtain income $(Y)$, the first stage regression equation is estimated by OLS based on the following specifications:

$$
\ln Y=\alpha+Z^{\prime} \gamma+X^{\prime} \beta+\epsilon \text {, }
$$

where $\ln Y$ is total rural income of the household, $\gamma$ is the parameter coefficients of the vector of the instrumental variables, and $Z$ are assumed to correlate with income $(Y)$ but not with the error term $\varepsilon$ in the structural equation 14 . The estimated PCFE of the household in (14) is now assumed to be unbiased. In order to estimate the effects of water and feed scarcity across the entire distribution of the dependent variables and to document the heterogeneity in the way food consumption responds to these scarcity variations, an alternative quantile regression was used following Koenker and Basset (1978).

\section{Per Capita Food Expenditure Estimation (PCFE)}

The PCFE is analyzed using the demand functions derived from maximized utility, subject to budget constraint and technology constraint of farm 
production, and its estimated result is presented in Tables 2 and 3, where walking distance and shadow prices are used as scarcity indicators using naive OLS and IV methods. Tables 2 and 3 compare results from naive OLS and 2SLS estimates for all variables of interest, namely water, grazing land, and crop residue distance. The potential candidate instruments used in the estimation were tested to check if they could pass the necessary requirements to be an instrument. Table 4 reports the test results for all scenarios presented in Table 2 and 3.

The Wu-Hausman $F$-test with a $p$-value less than 0.05 rejected the null hypothesis that OLS estimation is consistent or income is exogenous and motivates the use of instruments. Besides, the Sargan $\chi^{2}$-test fails to reject the null hypothesis that all instruments are uncorrelated with the error term in the structural model or all instruments are valid, and this helps to conclude that the instruments pass the over-identification requirement for all estimates. Finally, instruments were also tested if they could pass the second most important criteria that the instrument should be correlated or relevant to the endogenous variable income. To ensure the relevance of instruments, the Stock and Yogo (2005) $F$-test was employed and provided higher value $F$ statistics, a great deal higher than the rule of thumb of at least greater than 10 .

The first stage regression results of two-stage least square (2SLS) which are not reported here show that both instruments have a statistical relationship with income and carry the expected sign in all scenarios (Tables 2 and 3). Household income is often a major determinant of expenditure (Babalola and Isitor 2014). Total income of the household, which has a positive coefficient significantly affected PCFE. Column $(1,3$, and 5$)$ of Table 2 shows the income effect by estimating the consumption model using OLS estimator. The coefficient of income suggests that a 1 percent increase in income increases PCFE by around 0.044 percent, whereas the 2SLS result display that a 1 percent increase in total income leads to 0.059 percent increase in PCFE in all estimates. Because, as the income level of the household increases, the household purchasing power increases.

It turns out that this naive ordinary estimate grossly underestimates the income effect compared to effects from the IV-2SLS estimate. This implies that estimating the model using OLS is not the correct approach, and ignoring these differences would bias the income effect. Babalola and Isitor (2014), Njimanted (2006), and Thirumarpan (2013) also confirm that household income is one of the key determinants of food expenditure and food security in rural areas. I also report that farm output significantly affects household food consumption. The elasticity of PCFE with respect to the gross crop value equals to 0.063 percent for IV in the water scarcity estimates. Similar effects are found in the grazing and feed estimates presented in Table 2, columns 36. This is in line with Sarris, Savastano, and Christiaensen (2006), who found that agricultural productivity significantly affects PCFE in Ethiopia. The coefficient's sign and statistical significance show that livestock ownership is positively correlated with PCEF, suggesting that farmers with high herd size 
Table 2. IV Estimation of Log Per Capita Food Expenditure using Walking Distance

\begin{tabular}{|c|c|c|c|c|c|c|}
\hline & (OLS) & (IV) & (OLS) & (IV) & (OLS) & (IV) \\
\hline Variables & InPCFE & & & & & \\
\hline \multirow[t]{2}{*}{ Ln (output) } & $0.0940^{* * *}$ & $0.0629^{* * *}$ & $0.0909 * * *$ & $0.0631^{* * *}$ & $0.0986^{* * *}$ & $0.0685^{* * *}$ \\
\hline & $(0.0121)$ & $(0.0164)$ & $(0.0125)$ & $(0.0164)$ & $(0.0122)$ & $(0.0164)$ \\
\hline \multirow[t]{2}{*}{ Ln (livestock) } & $0.0336^{* * *}$ & $0.0287^{* *}$ & $0.0334^{* *}$ & $0.0298^{* *}$ & $0.0352^{* * *}$ & $0.0305^{* *}$ \\
\hline & $(0.0129)$ & $(0.0134)$ & $(0.0131)$ & $(0.0134)$ & $(0.0130)$ & $(0.0135)$ \\
\hline \multirow[t]{2}{*}{ Ln (family size) } & $-0.385^{* * *}$ & $-0.362^{* * *}$ & $-0.397^{* * *}$ & $-0.374^{* * *}$ & $-0.388^{* * *}$ & $-0.366^{* * *}$ \\
\hline & $(0.0529)$ & $(0.0551)$ & $(0.0535)$ & $(0.0554)$ & $(0.0534)$ & $(0.0554)$ \\
\hline \multirow[t]{2}{*}{ Gender $(1 / 0)$} & $-0.119^{* *}$ & $-0.136^{* *}$ & $-0.0993^{*}$ & $-0.114^{*}$ & $-0.115^{*}$ & $-0.133^{* *}$ \\
\hline & $(0.0588)$ & $(0.0608)$ & $(0.0590)$ & $(0.0607)$ & $(0.0593)$ & $(0.0613)$ \\
\hline \multirow[t]{2}{*}{ Information $(1 / 0)$} & 0.0591 & 0.0409 & 0.0454 & 0.0288 & 0.0487 & 0.0299 \\
\hline & $(0.0539)$ & $(0.0558)$ & $(0.0545)$ & $(0.0562)$ & $(0.0544)$ & $(0.0563)$ \\
\hline \multirow[t]{2}{*}{ Location $(1 / 0)$} & -0.0411 & -0.0519 & -0.114 & -0.129 & -0.149 & -0.169 \\
\hline & $(0.140)$ & $(0.144)$ & $(0.140)$ & $(0.143)$ & $(0.141)$ & $(0.145)$ \\
\hline \multirow[t]{2}{*}{ Ln (marketD) } & 0.00283 & 0.0166 & 0.00252 & 0.0165 & 0.00144 & 0.0146 \\
\hline & $(0.0337)$ & $(0.0350)$ & $(0.0340)$ & $(0.0353)$ & $(0.0340)$ & $(0.0353)$ \\
\hline \multirow[t]{2}{*}{ Ashock13 (1/0) } & $-0.489 * *$ & $-0.399 * *$ & $-0.550^{* * *}$ & $-0.463^{* *}$ & $-0.540^{* * *}$ & $-0.457^{* *}$ \\
\hline & $(0.191)$ & (0.199) & $(0.192)$ & $(0.200)$ & $(0.193)$ & $(0.200)$ \\
\hline \multirow[t]{2}{*}{ Ln (shocks) } & 0.212 & $0.345^{*}$ & 0.307 & $0.434^{* *}$ & 0.267 & $0.401^{*}$ \\
\hline & $(0.198)$ & $(0.209)$ & (0.199) & $(0.210)$ & $(0.200)$ & $(0.210)$ \\
\hline \multirow[t]{2}{*}{ Religion $(1 / 0)$} & $0.121^{*}$ & $0.146^{* *}$ & 0.101 & $0.124^{*}$ & 0.115 & $0.140^{*}$ \\
\hline & $(0.0700)$ & $(0.0726)$ & $(0.0705)$ & $(0.0727)$ & $(0.0706)$ & $(0.0730)$ \\
\hline
\end{tabular}


Table 2. Continued

\begin{tabular}{|c|c|c|c|c|c|c|}
\hline Variables & $\begin{array}{l}\text { (OLS) } \\
\text { InPCFE }\end{array}$ & $\begin{array}{l}\text { (IV) } \\
\text { InPCFE }\end{array}$ & $\begin{array}{l}\text { (OLS) } \\
\text { lnPCFE }\end{array}$ & $\begin{array}{l}\text { (IV) } \\
\text { lnPCFE }\end{array}$ & $\begin{array}{l}\text { (OLS) } \\
\text { InPCFE }\end{array}$ & $\begin{array}{l}\text { (IV) } \\
\text { InPCFE }\end{array}$ \\
\hline \multirow[t]{2}{*}{ Network $(1 / 0)$} & -0.0833 & $-0.172^{* * *}$ & -0.0761 & $-0.158^{* *}$ & -0.0729 & $-0.159^{* *}$ \\
\hline & $(0.0554)$ & $(0.0647)$ & $(0.0559)$ & $(0.0647)$ & $(0.0558)$ & (0.0649) \\
\hline \multirow[t]{2}{*}{ Age (years) } & -0.000477 & -0.000749 & -0.000535 & -0.000786 & -0.000554 & -0.000829 \\
\hline & $(0.00174)$ & $(0.00179)$ & $(0.00175)$ & $(0.00180)$ & $(0.00175)$ & $(0.00180)$ \\
\hline \multirow[t]{2}{*}{ Ln (income) } & $0.0440^{* * *}$ & $0.0565^{* * *}$ & $0.0433^{* * *}$ & $0.0552^{* * *}$ & $0.0439^{* * *}$ & $0.0562^{* * *}$ \\
\hline & $(0.00187)$ & $(0.00473)$ & (0.00189) & $(0.00476)$ & (0.00189) & $(0.00475)$ \\
\hline \multirow[t]{2}{*}{ Ln (WaterD) } & $-0.122^{* * *}$ & $-0.131^{* * *}$ & & & & \\
\hline & $(0.0309)$ & $(0.0320)$ & & & & \\
\hline \multirow[t]{2}{*}{ Ln (GrazingD) } & & & $-0.100^{* * *}$ & $-0.0888^{* *}$ & & \\
\hline & & & $(0.0336)$ & $(0.0347)$ & & \\
\hline \multirow[t]{2}{*}{ Ln (FeedD) } & & & & & $-0.0642^{* * *}$ & $-0.0716^{* * *}$ \\
\hline & & & & & $(0.0240)$ & $(0.0248)$ \\
\hline \multirow[t]{2}{*}{ Constant } & $6.018^{* * *}$ & $5.970^{* * *}$ & $6.046^{* * *}$ & $5.898^{* * *}$ & $5.917^{* * *}$ & $5.880^{* * *}$ \\
\hline & $(0.291)$ & $(0.300)$ & $(0.318)$ & $(0.330)$ & $(0.305)$ & (0.319) \\
\hline$R^{2}$ & 0.710 & 0.683 & 0.705 & 0.681 & 0.705 & 0.679 \\
\hline \multicolumn{7}{|l|}{ First stage } \\
\hline \multirow[t]{2}{*}{ Shock } & & $-20.132^{* * *}$ & & $-20.122^{* * *}$ & & $-20.140^{* * *}$ \\
\hline & & (2.1697) & & (2.1718) & & $(2.1686)$ \\
\hline \multirow[t]{2}{*}{ Rainfall } & & $0.1655^{* *}$ & & $0.1612^{* *}$ & & $0.1657^{* *}$ \\
\hline & & $(0.0573)$ & & $(0.0577)$ & & $(0.0572)$ \\
\hline Observation & 496 & 496 & 496 & 496 & 496 & 496 \\
\hline
\end{tabular}


Table 3. IV Estimation of Log Per Capita Food Expenditure using Shadow Prices

\begin{tabular}{|c|c|c|c|c|c|c|}
\hline Variables & $\begin{array}{l}\text { (OLS) } \\
\text { InPCFE }\end{array}$ & $\begin{array}{l}\text { (IV) } \\
\text { InPCFE }\end{array}$ & $\begin{array}{l}\text { (OLS) } \\
\text { InPCFE }\end{array}$ & $\begin{array}{l}\text { (IV) } \\
\ln \text { PCFE }\end{array}$ & $\begin{array}{l}\text { (OLS) } \\
\text { lnPCFF }\end{array}$ & (IV) \\
\hline vaitaivics & MII CIE & & & & & \\
\hline \multirow[t]{2}{*}{ Ln (output) } & $0.0998^{* * *}$ & $0.0698^{* * *}$ & $0.0984^{* * *}$ & $0.0677^{* * *}$ & $0.0842^{* * *}$ & $0.0587^{* * *}$ \\
\hline & $(0.0122)$ & $(0.0164)$ & $(0.0123)$ & $(0.0164)$ & $(0.0131)$ & $(0.0165)$ \\
\hline \multirow[t]{2}{*}{ Ln (livestock) } & $0.0381^{* * *}$ & $0.0337^{* *}$ & $0.0368^{* * *}$ & $0.0330^{* *}$ & $0.0363^{* * *}$ & $0.0327^{* *}$ \\
\hline & $(0.0130)$ & $(0.0134)$ & $(0.0130)$ & $(0.0135)$ & $(0.0129)$ & $(0.0133)$ \\
\hline \multirow[t]{2}{*}{ Ln (family size) } & $-0.388^{* * *}$ & $-0.366^{* * *}$ & $-0.380^{* * *}$ & $-0.356^{* * *}$ & $-0.379^{* * *}$ & $-0.360^{* * *}$ \\
\hline & $(0.0536)$ & $(0.0556)$ & $(0.0538)$ & $(0.0562)$ & $(0.0533)$ & $(0.0550)$ \\
\hline \multirow[t]{2}{*}{ Gender $(1 / 0)$} & $-0.103^{*}$ & $-0.118^{*}$ & -0.0846 & $-0.105^{*}$ & $-0.113^{*}$ & $-0.125^{* *}$ \\
\hline & $(0.0593)$ & $(0.0612)$ & $(0.0595)$ & $(0.0618)$ & $(0.0591)$ & $(0.0605)$ \\
\hline \multirow[t]{2}{*}{ Information $(1 / 0)$} & 0.0544 & 0.0363 & 0.0401 & 0.0250 & 0.0412 & 0.0267 \\
\hline & $(0.0546)$ & $(0.0564)$ & $(0.0546)$ & $(0.0567)$ & $(0.0544)$ & $(0.0559)$ \\
\hline \multirow[t]{2}{*}{ Location $(1 / 0)$} & -0.0480 & -0.0629 & -0.0567 & -0.0910 & -0.126 & -0.139 \\
\hline & $(0.145)$ & $(0.149)$ & $(0.141)$ & $(0.146)$ & $(0.140)$ & $(0.143)$ \\
\hline \multirow[t]{2}{*}{ Ln (MarketD) } & 0.00360 & 0.0173 & 0.000178 & 0.0150 & 0.00219 & 0.0157 \\
\hline & $(0.0341)$ & $(0.0354)$ & $(0.0342)$ & $(0.0357)$ & $(0.0339)$ & $(0.0350)$ \\
\hline \multirow[t]{2}{*}{ Ashock13 (1/0) } & $-0.494^{* *}$ & $-0.408^{* *}$ & $-0.526^{* * *}$ & $-0.431^{* *}$ & $-0.505^{* * *}$ & $-0.426^{* *}$ \\
\hline & (0.193) & $(0.201)$ & (0.192) & $(0.201)$ & $(0.192)$ & $(0.198)$ \\
\hline \multirow[t]{2}{*}{ Ln (shocks) } & 0.220 & $0.354^{*}$ & 0.241 & $0.396^{*}$ & 0.247 & $0.378^{*}$ \\
\hline & $(0.203)$ & $(0.214)$ & $(0.199)$ & $(0.212)$ & $(0.199)$ & $(0.210)$ \\
\hline \multirow[t]{2}{*}{ Religion (1/0) } & $0.119^{*}$ & $0.143^{*}$ & 0.0948 & $0.122^{*}$ & 0.111 & $0.132^{*}$ \\
\hline & $(0.0712)$ & $(0.0736)$ & $(0.0707)$ & $(0.0736)$ & $(0.0704)$ & $(0.0724)$ \\
\hline
\end{tabular}


Table 3. Continued

\begin{tabular}{|c|c|c|c|c|c|c|}
\hline Variables & $\begin{array}{l}\text { (OLS) } \\
\text { lnPCFE }\end{array}$ & $\begin{array}{l}\text { (IV) } \\
\text { lnPCFE }\end{array}$ & $\begin{array}{l}\text { (OLS) } \\
\text { lnPCFE }\end{array}$ & $\begin{array}{l}\text { (IV) } \\
\text { lnPCFE }\end{array}$ & $\begin{array}{l}\text { (OLS) } \\
\text { InPCFE }\end{array}$ & $\begin{array}{l}\text { (IV) } \\
\text { InPCFE }\end{array}$ \\
\hline \multirow[t]{2}{*}{ Network $(1 / 0)$} & -0.0839 & $-0.170^{* * *}$ & -0.0833 & $-0.167^{* * *}$ & -0.0677 & $-0.147^{* *}$ \\
\hline & $(0.0567)$ & $(0.0657)$ & $(0.0564)$ & $(0.0646)$ & (0.0557) & $(0.0645)$ \\
\hline \multirow[t]{2}{*}{ Age (years) } & -0.000615 & -0.000883 & -0.000760 & -0.000914 & -0.000504 & -0.000746 \\
\hline & $(0.00176)$ & $(0.00181)$ & $(0.00176)$ & $(0.00182)$ & $(0.00175)$ & $(0.00179)$ \\
\hline \multirow[t]{2}{*}{ Ln (income) } & $0.0437^{* * *}$ & $0.0560^{* * *}$ & $0.0426^{* * *}$ & $0.0558^{* * *}$ & $0.0432^{* * *}$ & $0.0547^{* * *}$ \\
\hline & $(0.00189)$ & $(0.00476)$ & $(0.00190)$ & $(0.00482)$ & (0.00189) & $(0.00478)$ \\
\hline \multirow[t]{2}{*}{ Ln (ShadowPW) } & $-0.0520^{*}$ & $-0.0528^{*}$ & & & & \\
\hline & $(0.0295)$ & $(0.0303)$ & & & & \\
\hline \multirow[t]{2}{*}{ Ln (ShadowPG) } & & & $-0.0972^{* * *}$ & $-0.0669^{* *}$ & & \\
\hline & & & $(0.0286)$ & $(0.0312)$ & & \\
\hline \multirow[t]{2}{*}{ Ln (ShadowPF) } & & & & & $-0.0525^{* * *}$ & $-0.0441^{* *}$ \\
\hline & & & & & $(0.0172)$ & $(0.0178)$ \\
\hline \multirow[t]{2}{*}{ Constant } & $5.753^{* * *}$ & $5.672^{* * *}$ & $6.052^{* * *}$ & $5.785^{* * *}$ & $5.835^{* * *}$ & $5.702^{* * *}$ \\
\hline & $(0.300)$ & $(0.309)$ & $(0.308)$ & $(0.331)$ & $(0.283)$ & $(0.294)$ \\
\hline$R^{2}$ & 0.702 & 0.676 & 0.705 & 0.675 & 0.706 & 0.684 \\
\hline \multicolumn{7}{|l|}{ First stage } \\
\hline \multirow[t]{2}{*}{ Average rainfall } & & $0.1665^{* * *}$ & & $0.1459^{* * *}$ & & $0.1629^{* * *}$ \\
\hline & & $(0.0 .0573)$ & & $(0.0581)$ & & $(0.0574)$ \\
\hline \multirow[t]{2}{*}{ Shock } & & $-20.1556^{* * *}$ & & $-19.932^{* * *}$ & & $-20.004^{* * *}$ \\
\hline & & $(2.184)$ & & $(2.1718)$ & & $(2.1765)$ \\
\hline Observation & 496 & 496 & 496 & 496 & 496 & 496 \\
\hline
\end{tabular}

$P$-Values are for slopes; ${ }^{* * *} P<0.01,{ }^{* *} P<0.05$, and ${ }^{*} P<0.10=$ Significant at 1,5 , and $10 \%$ probability level respectively. 
Table 4. Instrumental Variables Tests

\begin{tabular}{lccc}
\hline Estimates & $\begin{array}{l}\text { Endogeneity } \\
\text { Criteria }\end{array}$ & Validity & Relevance \\
\cline { 2 - 4 } & $\begin{array}{l}\text { Wu-Hausman } \\
(\boldsymbol{P} \text {-value })\end{array}$ & $\begin{array}{l}\text { Sargan } \\
(\boldsymbol{P} \text {-value })\end{array}$ & $\begin{array}{l}\text { Stock and } \\
\text { Yogo, } \boldsymbol{F} \text {-value }\end{array}$ \\
\hline Water scarcity model & $(0.0008)$ & $(0.5562)$ & 42.28 \\
Gazing scarcity model & $(0.0011)$ & $(0.5236)$ & 42.27 \\
Straw scarcity model & $(0.0013)$ & $(0.5417)$ & 42.56 \\
\hline
\end{tabular}

have a higher food consumption expenditure. Dercon, Hoddinott, and Woldehanna (2005) in Ethiopia and Sarris, Savastano, and Christiaensen (2006) in Tanzania found a similar result.

Another significant variable is household size, leading to 0.363 percent decrease in PCFE for 1 percent increase in the number of members of the household. This result is in line with Dercon, Hoddinott, and Woldehanna (2005) and Bezu et al. (2014) in Ethiopia and Sarris et al. (2006) in Tanzania. A household with a male head has a disadvantage of 13.6 percent decrement in PCFE against the findings of Dercon, Hoddinott, and Woldehanna (2005) in Ethiopia. Individual farmers experiencing an animal shock at least once in the previous year have 39.9, 46.3 and 45.7 percent lower PCFE for the three cases taking the estimated value of IV in Table 2. In line with this, Dercon (2004) found that a livestock shock negatively affects PCFE in rural Ethiopia.

The coefficient of religion is 14.6 percent and is statistically significant, implying that orthodox households have 0.146 percent PCFE higher than the Muslim group, referring to the IV estimate, which is opposite of the result of Oldiges (2012) in India. The negative and significant sign of network shows that individuals who got social supports have 17.2 percent less PCFE, implying that supports from relatives or friends are not adequate enough to cover food expenditure for the recipient households. A similar result was found by Sarris, Savastano, and Christiaensen (2006). Other insignificant variables are proximity to market (positive), information (positive), and the age of the household head (negative) in line with Matchaya and Chilonda (2012) in Malawi.

The main interest of this paper is to explore how time spent for animal feed and water searching directly affects PCFE, and our result is in line with the downward spiral hypothesis (Ostrom et al. 1999). Using the distance indicator in Table 2, time spent looking for water and grazing land has resulted in a negative sign, and it is found to be an important factor of PCFE. A 1 percent increase in minutes traveled to reach water and grazing land leads to a 0.131 and 0.088 percent decrease in PCFE, respectively, using IV. 
In addition, a 1 percent increase in minutes traveled to collect crop residue leads to a 0.072 percent decrease in PCFE. Likewise, my results from the shadow price (Table 3) indicate that scarcity of resources has an important impact on the food demand, with the expected result that an increase in the shadow price of water, grazing, and crop residue by 1 percent reduces PCFE by $0.053,0.067$, and 0.044 percent, respectively. This implies that the scarcity has a negative effect on households' PCFE, either by affecting livestock production directly, affecting crop or off-farm income via labor reallocation or through its direct impact on time leisure consumption.

This result agrees with Bandyopadhyay, Shyamsundar, and Baccini (2011), whose result revealed that the scarcity of biomass negatively affected rural PCFE in Malawi. Baland et al. (2010) also showed that an increase in firewood collection time by $1 \mathrm{~h} /$ day is equivalent to an income loss of about 1 percent in Nepal. Bhattacharya and Innes (2006) highlighted that forest degradation spurs rural poverty in SSA. This supports the argument by Chopra et al. (2007), Cooke, Köhlin, and Hyde (2008), Kumar and Hotchkiss (1988) and Tangka and Jabbar (2005), whose study conclude that feed and water scarcity reduces livestock, crop, and nonfarm productivity as well as access to food, resulting in less food security and low human welfare by traveling long distance with an animal in search of feed and water in less developing countries.

Estimation of food security is presented in Table 5; the model had about 38 percent prediction power, compared to 48 percent observed probability. The negative significant relationship between the shadow prices and the household food security implies that households that spend more time on searching for water, grazing, and crop residue are more likely to be food insecure than their counterparts with nearer distance. The coefficients from marginal effect indicated that increasing the shadow prices of water, grazing, and crop residue reduces the probability of food security by $0.0594,0.0533$, and 0.0418 percent, respectively, supporting the arguments forwarded by Cooke, Köhlin, and Hyde (2008) and Alemu, Damte, and Deribe (2015). The results further show that the probability of food security increases significantly and consistently with farm output, total income, and religion in favor of Ogundari (2017) but declines with family and herd size, supporting the results from Feleke et al. (2005).

An alternative is to estimate quantile regressions on food expenditure, to capture the effects of these scarce variables across the entire distribution of the dependent of the variable. A quantile regression is a method of estimating functional relationships between variables for all portions of a distribution function (Koenker and Bassett 1978). The hypothesis that the impact of feed and water scarcity strongly increases from the bottom to the top quartile is tested using this quantile regression, and results are displayed in Table 6. The elasticity values associated with a 1 percent change in distance to a grazing land on food production range from -0.0996 percent for the forth quantile to -0.171 percent of top quartile with a median value 
Table 5. Probit Estimation of Food Security using Walking Distance

\begin{tabular}{|c|c|c|c|}
\hline & (ME) & (ME) & (ME) \\
\hline Variables & HHFS & & \\
\hline \multirow[t]{2}{*}{ Ln (output) } & $0.0280^{* *}$ & $0.0315^{* *}$ & 0.0153 \\
\hline & $(0.0134)$ & $(0.0140)$ & $(0.0145)$ \\
\hline \multirow[t]{2}{*}{ Ln (livestock) } & $-0.0257^{* *}$ & $-0.0236^{*}$ & $-0.0269^{* *}$ \\
\hline & $(0.0120)$ & $(0.0122)$ & $(0.0121)$ \\
\hline \multirow[t]{2}{*}{ Ln (family size) } & $-0.203^{* * *}$ & $-0.202^{* * *}$ & $-0.206^{* * *}$ \\
\hline & $(0.0591)$ & $(0.0596)$ & $(0.0598)$ \\
\hline \multirow[t]{2}{*}{ Gender $(1 / 0)$} & -0.0880 & -0.0596 & -0.0853 \\
\hline & $(0.0670)$ & $(0.0669)$ & $(0.0668)$ \\
\hline \multirow[t]{2}{*}{ Information $(1 / 0)$} & 0.0629 & 0.0358 & 0.0506 \\
\hline & $(0.0584)$ & $(0.0592)$ & $(0.0585)$ \\
\hline \multirow[t]{2}{*}{ Location $(1 / 0)$} & -0.0963 & -0.126 & -0.169 \\
\hline & $(0.146)$ & $(0.134)$ & $(0.124)$ \\
\hline \multirow[t]{2}{*}{ Ln (marketD) } & -0.0447 & -0.0540 & -0.0409 \\
\hline & $(0.0376)$ & $(0.0379)$ & $(0.0374)$ \\
\hline \multirow[t]{2}{*}{ Shock13 (1/0) } & -0.138 & -0.155 & -0.151 \\
\hline & $(0.197)$ & (0.187) & $(0.189)$ \\
\hline \multirow[t]{2}{*}{ Ln (shocks) } & 0.355 & $0.404^{*}$ & $0.395^{*}$ \\
\hline & $(0.240)$ & $(0.219)$ & $(0.224)$ \\
\hline \multirow[t]{2}{*}{ Religion $(1 / 0)$} & $0.147^{* *}$ & $0.135^{* *}$ & $0.135^{* *}$ \\
\hline & $(0.0649)$ & $(0.0653)$ & $(0.0653)$ \\
\hline \multirow[t]{2}{*}{ Network (1/0) } & -0.0703 & -0.0419 & -0.0482 \\
\hline & $(0.0645)$ & $(0.0640)$ & $(0.0636)$ \\
\hline \multirow[t]{2}{*}{ Age (years) } & -0.000700 & -0.000232 & -0.000741 \\
\hline & $(0.00185)$ & $(0.00185)$ & $(0.00185)$ \\
\hline \multirow[t]{2}{*}{ Ln (income) } & $0.0327^{* * *}$ & $0.0321^{* * *}$ & $0.0324^{* * *}$ \\
\hline & $(0.00293)$ & $(0.00293)$ & $(0.00295)$ \\
\hline \multirow[t]{2}{*}{ Ln (ShadowPW) } & $-0.0594^{*}$ & & \\
\hline & $(0.0327)$ & & \\
\hline \multirow[t]{2}{*}{ Ln (ShadowPG) } & & $-0.0533^{*}$ & \\
\hline & & $(0.0307)$ & \\
\hline \multirow[t]{2}{*}{ Ln (ShadowPF) } & & & $-0.0418^{* *}$ \\
\hline & & & $(0.0185)$ \\
\hline Observed Probability & 0.4824 & 0.4792 & 0.4824 \\
\hline
\end{tabular}


Table 5. Continued

\begin{tabular}{lccc}
\hline & (ME) & (ME) & (ME) \\
Variables & HHFS & HHFS & HHFS \\
\hline Predicted probability & 0.3803 & 0.3723 & 0.3792 \\
Pseudo $R^{2}$ & 0.4379 & 0.4404 & 0.4405 \\
Observation & 514 & 514 & 514 \\
\hline
\end{tabular}

$P$-Values are for slopes; ${ }^{* * *} P<0.01 ;{ }^{* *} P<0.05$ and ${ }^{*} P<0.10=$ Significant at 1,5 and $10 \%$ probability level respectively.

Table 6. Effect of Water, Grazing and Feed Scarcity on Log PCFE using Quintile Regression

\begin{tabular}{lccccc}
\hline & (PCFE) & (PCFE) & (PCFE) & (PCFE) & (PCFE) \\
Variables & q10 & q25 & q50 & q75 & q90 \\
\hline \multirow{2}{*}{ Ln (ShadowPW) } & -0.00210 & -0.0102 & $-0.0644^{* *}$ & -0.0341 & -0.0299 \\
& $(0.0546)$ & $(0.0291)$ & $(0.0259)$ & $(0.0268)$ & $(0.0457)$ \\
Ln (ShadowPG) & -0.0608 & -0.0345 & $-0.100^{* * *}$ & $-0.0996^{* * *}$ & $-0.171^{* * *}$ \\
& $(0.0408)$ & $(0.0274)$ & $(0.0313)$ & $(0.0289)$ & $(0.0490)$ \\
Ln (ShadowPF) & -0.0413 & -0.00441 & -0.00858 & -0.0194 & $-0.0691^{* * *}$ \\
& $(0.0372)$ & $(0.0247)$ & $(0.0181)$ & $(0.0165)$ & $(0.0260)$ \\
Observations & 496 & 496 & 496 & 496 & 496 \\
\hline
\end{tabular}

$P$-Values are for slopes; ${ }^{* * *} P<0.01$; ${ }^{* *} P<0.05$ and ${ }^{*} P<0.10=$ Significant at 1,5 , and $10 \%$ probability level respectively.

of -0.100 percent in Table 6 . The effect of a 1 percent increase in distance to crop residue source brings about a 0.069 percent reduction in food expenditure only for the top category, while the effect of water is 0.064 percent at the median value. This analysis is relevant not only from the perspective of econometric correctness but also for the purposes of policy. This is an evidence that treating all quantiles as one and hence estimating only one coefficient such as in OLS would be misleading both for policy and inference.

\section{Total Effect of Feed and Water Scarcity on Food Security}

This section discusses the total effect of an animal water and feed scarcity on total welfare effect. Based on equation 12, the total effect is simply calculated by taking the slope coefficient of income in the consumption regression multiplied by the coefficient of time allocation in the production estimation, plus the coefficient of time allocation in the consumption regression that is 
the total effect of grazing scarcity is the slope coefficient of income $\left(d C_{d} / d Y\right)$ in the consumption regression multiplied by the coefficient of time spent for searching grazing in the production estimation $\left(d Y / d L_{c}\right)$ plus the coefficient of time spent for searching grazing in the consumption regression $\left(d C_{d} / d L_{c}\right)$; the total effect of water scarcity is the slope coefficient of income $\left(d C_{d} / d Y\right)$ in the consumption regression multiplied by the coefficient of time spent for searching water in the production estimation $\left(d Y / d L_{c}\right)$ plus the coefficient of time spent for searching water in the consumption regression $\left(d C_{d} / d L_{c}\right)$ and the total effect of straw scarcity is the slope coefficient of income $\left(d C_{d} / d Y\right)$ in the consumption regression multiplied by the coefficient of time spent for collecting straw in the production estimation $\left(d Y / d L_{c}\right)$ plus the coefficient of time spent for collecting straw in the consumption regression $\left(d C_{d} / d L_{c}\right)$. However, the coefficient of time spent for searching grazing and water or for collecting straw in the production estimation $\left(d Y / d L_{c}\right)$ is not available here; it is available upon request.

Based on Table 7, the effects of time spent searching for water, feed, and collecting straw on PCFE are $-0.142,-0.102$, and -0.092 percent, respectively, using distance measure. This implies that for a 1 percent increase in minutes traveled to a water, grazing, and straw source, PCFE decreases by $0.142,0.102$, and 0.092 percent, respectively. If the median household in this data spends about 60 min daily to look for water and feed source and has PCFE 2490 ETB, decreasing traveling minutes to a water, grazing, and straw sources by $0.6 \mathrm{~min}$ /day will increase PCFE by 354 (2490*0.142) ETB, $254(2490 * 0.102)$ ETB, and 229 (2490*0.092) ETB, respectively, for the median household using panel A distance value (Table 7).

\section{Conclusion and Suggestion}

The scarcity of grazing and water for an animal has negative effects on a household's welfare and food security, either by affecting livestock production directly, affecting crop or off-farm income via labor reallocation, or through its direct impact on time leisure consumption. My research questions focus on the relationship between natural resources scarcity and PCFE (welfare) and food security. In this paper, I have explored these effects using distance and shadow price as resource scarcity indicators in Northern Ethiopia based on 518 sample farmers. To address the first objective of my research, I employed the IV 2SLS estimation, and the second question is addressed by estimating a probit model for food security. The descriptive result shows that about 48 percent of households were food secure. while 52 percent were food insecure given that two-thirds of the average of all households' PCFE was 1660 ETB.

My results confirmed the theoretical prediction that resource scarcity affects households' welfare and food security adversely as predicted by the downward spiral hypothesis (Ostrom et al. 1999). The results in this paper provide an interesting picture of smallholders in Ethiopia and hint at several areas that 
Table 7. Aggregate Effect of Water and Feed Scarcity on Output, Food Expenditure, and Food Security

\begin{tabular}{lccc}
\hline Estimates & Effect on output (Y) & Effect on PCFE & Total effect \\
\hline Panel A using distance value & $\frac{d Y}{d T}$ & $\frac{d P C F E}{d T}$ & $\frac{d P C F E}{d Y} \frac{d Y}{d T}+\frac{d P C F E}{d T}$ \\
Water scarcity $\left(T_{w}\right)$ & -0.155 & -0.133 & -0.142 \\
Grazing scarcity $\left(T_{f}\right)$ & -0.279 & -0.086 & -0.102 \\
Straw scarcity $\left(T_{t}\right)$ & -0.328 & -0.0731 & -0.092 \\
Panel B using shadow price & & & \\
Water scarcity $\left(T_{w}\right)$ & -0.074 & -0.0529 & -0.057 \\
Grazing scarcity $\left(T_{f}\right)$ & -0.094 & -0.0627 & -0.068 \\
Straw scarcity $\left(T_{t}\right)$ & -0.154 & -0.0421 & -0.051 \\
\hline
\end{tabular}

could be important for improving food security and welfare in general. As expected, it appears that time spent looking for water and feed has a significant and negative effect on PCFE and food security. In aggregate, reducing time spent looking for water by 1 percent leads to an increase in PCFE by 0.131 percent and food security by 0.0594 percent. Similarly, a 1 percent decrease in time wastage for searching for grazing land increases PCFE and aggregate food security by 0.088 percent and 0.053 percent, respectively. Likewise, an increment of 0.0716 percent in PCFE and 0.0418 percent in food security is achieved by a 1 percent reduction in crop residue transporting time per tripe.

The impact of time spent searching for water and feed and collecting straw on PCFE is $-0.142,-0.102$ and -0.092 percent, respectively, using distance measure in Table 7. The median household in these data spends about 60 min looking for water and feed sources and has a PCFE of 2490 ETB. For the median household, decreasing traveling minutes to water, grazing and straw source by $0.6(60 / 100)$ minutes will increase PCFE by $354(2490 * 0.142)$ ETB, $254(2490 * 0.102)$ ETB, and $229(2490 * 0.092)$ ETB, respectively.

Depending on results from the quantile regression, the effect of water and feed scarcity is not uniform across the food income group, implying that its negative effect strongly increases from the bottom (poor) to the top (rich) quantile. For instance, the elasticity values associated with a 1 percent change in distance to a grazing land on food production ranges from -0.0996 percent for the fourth quantile to -0.171 percent of the top quartile with a median value of -0.100 percent. The effect of a 1 percent increase in distance to crop residue source brings about a 0.069 percent reduction in food expenditure only for the top category, while the effect of water is 0.064 percent at the median value. This analysis is relevant for the purposes of policy. If coefficients for a policy variable differ in different quantiles of the 
output variable, it implies that a policy change seeking to address issues of resource scarcity will have different effects on different households based on their position on the distribution of the food income variable.

In general, this study can be helpful for policymakers working to alleviate animal water and feed problems in Ethiopia to justify their actions with empirical results. The findings play a great role in the understanding of the linkage between welfare, food security, and environmental resources such as grazing and water scarcity. Three areas of policy intervention can be emerged as relevant. The first involves policies and institutions that facilitate easier access to animal water tap by advocating on emergency relief grounds. The second area of policy intervention involves the introduction of more efficient animal feed management strategies such as stall feeding and rotational grazing with the help of improved cow adoption that can improve cattle production and reduce land degradation. A policy that sought to increase household food consumption would greatly affect the highest quantile more than those who are in the lowest quantile of food production distribution.

\section{References}

Abdulai, A., and W. Huffman. 2014. "The Adoption and Impact of Soil and Water Conservation Technology, an Endogenous Switching Regression Application." Land Economics 90(1): 26-43.

Adewuyi, S.A., T.E. Mafimisebi, and P.O. Awe. 2009. "Food Expenditure Patterns among Urban Households in Ibadan Southwest Local Government Area, Oyo State." Journal of Humanities, Social Science and Creative Arts 4(1): 82-89.

Aggrey, N., S. Wambugu, J. Karugia, and E. Wanga. 2010. "An Investigation of the PovertyEnvironmental Degradation Nexus: A Case Study of Katonga Basin in Uganda." Research Journal of Environmental and Earth Sciences 2(2): 82-88.

Alemu, M., A. Damte, and R. Deribe. 2015. "The Impact of Natural Resource Scarcity on Agriculture in Ethiopia, The environment for Development." Discussion PaperResources for the Future (RFF) 15-13.

Aluko, M.A.O. 2004. "Sustainable Development, Environmental Degradation and the Entrenchment of Poverty in the Niger Delta of Nigeria." Journal of human ecology 15 (1): 63-68.

Angrist, J.D., and W. Evans. 1998. “Children and Their Parents' Labor Supply: Evidence from Exogenous Variation in Family Size." The American Economic Review 88(3): 450-477.

Asfaw, S., B. Shiferaw, F. Simtowe, and L. Lipper. 2012. "Impact of Modern Agricultural Technologies on Smallholder Welfare: Evidence from Tanzania and Ethiopia." Food Policy 37(3): 283-295.

Asresie, A., and L. Zemedu. 2015. "The Contribution of Livestock Sector in Ethiopian Economy." A Review. Advances in Life Science and Technology 29: 79-90.

Babalola, D.A., and S.U. Isitor. 2014. "Analysis of the Determinants of Food Expenditure Patterns among Urban Households in Nigeria: Evidence from Lagos State." Journal of Agriculture and Veterinary Science 7(5): 71-75.

Bandyopadhyay, S., P. Shyamsundar, and A. Baccini. 2011. "Forests, Biomass Use and Poverty in Malawi." Ecological Economics 70(12): 2461-2471.

Baland, J.M., P. Bardhan, S. Das, D. Mookherjee, and R. Sarkar. 2010. "The Environmental Impact of Poverty: Evidence from Firewood Collection in Rural Nepal." Economic Development and Cultural Change 59(1): 23-61. 
Becker, G.S. 1991. Treatise on the Family (2nd edition). Cambridge, MA: Harvard University Press.

Belay, D., E. Getachew, T. Azage, and B.H. Hegde. 2013. "Farmers' Perceived Livestock Production Constraints in Ginchi Watershed Area: Result of Participatory Rural Appraisal." International Journal of Livestock Production 4(8): 128-134.

Bewket, W. 2011. "Farmer's Knowledge of Soil Erosion and Control Measures in the Northern Highlands of Ethiopia." African Geographical Review 30(2): 53-70.

Bezabih, M.Y., and G. Berhane. 2014. "Livestock Production Systems Analysis." American International Journal of Contemporary Scientific Research 1(2): 16-51.

Bezu, S., G.T. Kassie, B. Shiferaw, and J. Ricker-Gilbert. 2014. "Impact of Improved Maize Adoption on Welfare of Farm Households in Malawi: A Panel Data Analysis." World Development 59: 120-131.

Bhattacharya, H., and R. Innes. 2006. "Is There a Nexus Between Poverty and Environment in Rural India?" Paper Presented at the American Agricultural Economics Association Annual Meeting, July 23-26, Long Beach, California.

Bishu, K.G. 2014. "Risk Management and the Potential of Cattle Insurance in Tigray, Northern Ethiopia." PhD thesis, University College Cork.

Boone, C., P. Glick, and D.E. Sahn. 2011. "Household Water Supply Choice and Time Allocated to Water Collection: Evidence from Madagascar." Journal of Development Studies 47(12): 1826-1850.

Çağlayan, E., and M. Astar. 2012. "A Micro-Econometric Analysis of Household Consumption Expenditure Determinants for Both Rural and Urban Areas in Turkey." American International Journal of Contemporary Research 2(2): 27-34.

Chopra, N., S. Singh, S. Gupta, U. Narain, and K.V.T. Veld. 2007. "Who Collects Resources in Degraded Environment? A Case Study from Jhabua District, India." SANDEE Working Paper No. 23-07.

Cooke, P.A. 1998. "The Effect of Environmental Good Scarcity on Own-Farm Labor Allocation: The Case of Agricultural Households in Rural Nepal." Environment and Development Economics 3(4): 443-469.

Cooke, P., G. Köhlin, and W.F. Hyde. 2008. "Fuelwood, Forests, and Community ManagementEvidence from Household Studies." Environment and Development Economics 13(1): 103-135.

Damte, A., S.F. Koch, and A. Mekonnen. 2012. "Coping with Fuelwood Scarcity. Household Responses in Rural Ethiopia." Environment for Development Discussion Paper Series 12-01. 1-34. Addis Ababa: Environment for Development.

Dasgupta, P. 2007. "Nature and the Economy." Journal of Applied Ecology 44(3): 475-487.

Dercon, S. 2004. "Growth, and Shocks: Evidence from Rural Ethiopia." Journal of Development Economics 74(2): 309-329.

Dercon, S., J. Hoddinott, and T. Woldehanna. 2005. "Shocks and Consumption in 15 Ethiopian Villages, 1999-2004." Journal of African Economies 14(4): 559-585.

Di Falco, S., M. Veronesi, and M. Yesuf. 2011. "Does Adaptation to Climate Change Provide Food Security? A Micro-Perspective from Ethiopia." American Journal of Agricultural Economics 93(3): 829-846.

Faridi, R., and S.N. Wadood. 2010. "An Econometric Assessment of Household Food Security in Bangladesh." The Bangladesh Development Studies 33(3): 97-111.

Feleke, S.T., R.L. Kilmer, and C.H. Gladwin. 2005. "Determinants of Food Security in Southern Ethiopia at the Household Level." Agricultural Economics 33(3): 351-363.

Felleke, G., and G. Geda. 2001. "The Ethiopian Dairy Development Policy:" a draft policy document, Ministry of Agriculture (MoA), Addis Ababa, Ethiopia.

Freeman, A., S. Kaitibie, S. Moyo, and B. Perry. 2007. "Livestock, Livelihoods and Vulnerability in Selected SADC Countries (Lesotho, Malawi and Zambia)." International Livestock Research Institute (ILRI) Research Report, 8.

Gaiha, R., N. Kaicker, K. Imai, V.S. Kulkarni, and G. Thapa. 2014. "Dietary Shift and Diet Quality in India: An Analysis Based on 50th, 61st and 66th Rounds of NSS." In R. Jha, R. Gaiha, A. 
Deolalikar, eds., Handbook on Food: Demand, Supply, Sustainability and Security 177-203, Edward Elgar, Gloucestershire, UK.

Gebreegziabher, T, J. Nyssen, B. Govaerts, F. Getnet, M. Behailu, M. Haile, and J. Deckers. 2009. "Contour Furrows for in-situ Soil and Water Conservation, Tigray, Northern Ethiopia." Soil \& Tillage Research 103(2): 257-264.

Gebremedhin, B. 2009. "Feed Marketing in Ethiopia: Results of Rapid Market Appraisal." Working Paper No. 15. ILRI (aka ILCA and ILRAD). Nairobi, Kenya.

Hassen, A., A. Ebro, M. Kurtu, and A.C. Treydte. 2010. "Livestock Feed Resources Utilization and Management as Influenced by Altitude in the Central Highlands of Ethiopia Livestock Research for Rural Development 22(229) [online]." Available at http://www. lrrd.org/lrrd22/12/hass22229.htm (accessed April 7, 2016).

Hidalgo, F.D., S. Naidu, S. Nichter, and N. Richardson. 2010. "Occupational Choices: Economic Determinants of Land Invasions." The Review of Economics and Statistics, forthcoming.

Hoddinott, J., J.A. Maluccio, J.R. Behrman, R. Flores, and R. Martorell. 2008. "Effect of a Nutrition Intervention During Early Childhood on Economic Productivity in Guatemalan Adults." The Lancet 371(9610): 411-416.

Ilyin, S. 2011. "The Looming Threat of Overgrazing: Effects and Recommendations." Congressional Hunger Center. [Online] Available at http://Hungercenter.wpengine. netdna-cdn.com/wp-contentLooming-Threat-of-Overgrazing-Ilyin.pdf (uploaded 09, 2011).

Khan, H. 2008. "Poverty, Environment and Economic Growth: Exploring the Links among Three Complex Issues with Specific Focus on Pakistan's Case." Environment Development Sustainability 10(6): 913-929.

Koenker, R., and G. Bassett. 1978. "Regression Quantiles." Econometrica 46(1): 33-50.

Kumar, S.K., and D. Hotchkiss. 1988. "Consequences of Deforestation for Women's Time Allocation, Agricultural Production, and Nutrition in Hill Areas of Nepal," Research Report 69, International Food Policy Research Institute, Washington, DC.

Lal, R., and B.A. Stewart. 2010. Food Security and Soil Quality. Advances in Soil Science. CRC Press.

Magnan, N., D.M. Larson, and J.E. Taylor. 2012. “Stuck on Stubble? The Non-Market Value of Agricultural Byproducts for Diversified Farmers in Morocco." American Journal of Agricultural Economics 94(5): 1055-1069.

Matchaya, G., and P. Chilonda. 2012. "Estimating Effects of Constraints on Food Security in Malawi: Policy Lessons from Regressions Quantiles." Applied Econometrics and International Development 12(2): 165-191.

Mekonnen, D., E. Bryan, T. Alemu, and C. Ringler. 2017. "Food Versus Fuel: Examining Tradeoffs in the Allocation of Biomass Energy Sources to Domestic and Productive Uses in Ethiopia." Agricultural Economics 48(4): 425-435.

Mignouna, D. B., T. Abdoulaye, A. Alene, V.M. Manyong, P.N. Dontsop, J.H. Ainembabazi, and R. Asiedu. 2015. "A Microecnometrics Analysis of Household Consumption Expenditure Determinants in Yam-Growing Areas of Nigeria and Ghana." Tropicultura 33(3): 226-237.

Narain, U., S. Gupta, and K. Van't Veld. 2008. “Poverty and the Environment: Exploring the Relationship Between Household Incomes, Private Assets, and Natural Assets." Land Economics 84(1): 148-167.

Njimanted, G.F. 2006. "Econometric Model of Poverty in Cameroon: A System Estimation Approach." International Review of Business Research Papers 2(2): 30-46.

Ogundari, K. 2017. "Categorizing Households into Different Food Security States in Nigeria: The Socio-Economic and Demographic Determinants." Agricultural and Food Economics 5(8): 1-20.

Oldiges, C. 2012. "Cereal Consumption and Per Capita Income in India." Economic \& Political Weekly 47(6): 63.

Ostrom, E., J. Burger, C.B. Field, R.B. Norgaard, and D. Policansky. 1999. "Revisiting the Commons: Local Lessons, Global Challenges." Science 284(5412): 278-282. 
Oum, T.H. 1989. "Alternative demand models and their elasticity estimates." Journal of Transport Economics and Policy 23(2):163-187.

Palmer, C., and MacGregor, J. 2009. "Fuelwood Scarcity, Energy Substitution, and Rural Livelihoods in Namibia." Environment and Development Economics 14(6): 693-715.

Randolph, T.F., E. Schelling, D. Grace, C.F. Nicholson, J.L. Leroy, D.C. Cole, and M. Ruel. 2007. "Role of Livestock in Human Nutrition and Health for Poverty Reduction in Developing Countries." Journal of Animal Science 85(11): 2788-2800.

Sarris, A., S. Savastano, and L. Christiaensen. 2006. "The Role of Agriculture in Reducing Poverty in Tanzania: A Household Perspective from Rural Kilimanjaro and Ruvuma," FAO Commodity and Trade Policy Research Working Paper No.19.

Sileshi, Z., A. Tegegne, and G.T. Tsadik. 2003. "Water Resources for Livestock in Ethiopia: Implications for Research and Development, Integrated Water and Land Management Research and Capacity Building Priorities for Ethiopia." Research Paper No. 66.

Smith, L.C., and A. Subandoro. 2007. "Measuring Food Security using Household Expenditure Surveys." (Vol. 3). Washington, DC: International Food Policy Research Institute.

Steinfeld, H., P. Gerber, T.D. Wassenaar, V. Castel, and C. de Haan. 2006. Livestock's Long Shadow: Environmental Issues and Options. Rome: Food \& Agriculture Organization.

Stock, J. H., and M. Yogo. 2005. "Testing for Weak Instruments in Linear IV Regression." In D. W.K. Andrews \& J.H. Stock, eds., Identification and Inference for Econometric Models. Cambridge, UK: Cambridge University Press 80-108.

Strauss, J. 1983. "Socioeconomic Determinants of Food Consumption and Production in Rural Sierra Leone: Application of an Agricultural Household Model with Several Commodities." MSU International Development Papers. Department of Agricultural Economics, Michigan State University, East Lansing.

Strauss, J. 1986. "Estimating the Determinants of Food Consumption and Caloric Availability in Rural Sierra Leone." In I. Singh, L. Squire, and J. Strauss eds., Agricultural Household Models: Extensions, Applications, and Policy. Baltimore: Johns Hopkins University Press 116-152.

Swanepoel, F., A. Stroebel, and S. Moyo. 2010. "The Role of Livestock in Developing Communities: Enhancing Multifunctionality." Co-published by the Technical Centre for Agricultural and Rural Cooperation (CTA). South Africa 978(0):86886-7984.

Tangka, F.K., and M.A. Jabbar. 2005. "Implications of Feed Scarcity for Gender Roles in Ruminant Livestock Production" Working Paper No. 182872.

Tegegne, S.D. 2012. Livestock Water Productivity (LWP) "Improvement in the Mixed CropLivestock System of Ethiopian Highlands, Amhara Region: A Gendered Sustainable Livelihood Approach to Target LWP Interventions for Rural Poverty Reduction." A PhD thesis, Rheinischen Friedrich-Wilhelm's-University of Bonn, Germany.

Tesfa, A., and S. Mekuriaw. 2014. "The Effect of Land Degradation on Farm Size Dynamics and Crop-Livestock Farming System in Ethiopia: A Review." Open Journal of Soil Science 4(01): $1-5$.

Thirumarpan, K. 2013. "Determinants of Household Food Expenditure among Rural Households of Ampara District." Proceedings, 4th International Symposium, SEUSL, Social Science and Humanities 325-330.

Titus, B., and G. Adetokunbo. 2007. "An Analysis of Food Security Situation among Nigerian Urban Households: Evidence from Lagos State, Nigeria." Journal of Central European Agriculture 8(3): 397-406.

Yilma, Z., E. Guernebleich, A. Sebsibe, and R. Fombad. 2011. "A Review of the Ethiopian Dairy Sector. Addis Ababa, Ethiopia." FAO Sub-Regional Office for Eastern Africa (FAO/SFE).

Yimer, A.A. 2005. "Farm Management in Mixed Crop-Livestock Systems in the Northern Highlands of Ethiopia." PhD thesis, Wageningen University.

Wooldridge, J.M. 2009. Introductory Econometrics: A Modern Approach (4th edition). Mason: South-Western CENGAGE Learning.

World Bank. 2012. “Word Development Indicators 2012." Washington DC: The World Bank. 